\title{
Comparison between Staphylococcus aureus, strains iso- lated from medical students in pre-clinical formation and clinical training
}

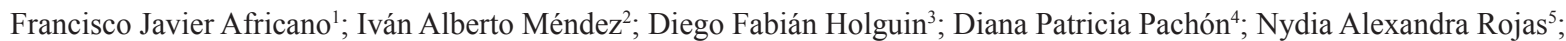
Iván Mauricio Gonzalez ${ }^{6}$

1 Internship student, School of Medicine, Universidad Militar Nueva Granada.

2 MSc Microbiology, Professor School of Medicine, Universidad Militar Nueva Granada, Patogenicidad Microbiana Team research.

3 Internship student, School of Medicine, Universidad Militar Nueva Granada.

4 MSc Microbiology, Professor School of Medicine, Universidad Militar Nueva Granada, Patogenicidad Microbiana Team research.

5 MD, Cd MSc Public Health, Professor School of Medicine, Universidad Militar Nueva Granada.

6 Internship student, School of Medicine, Universidad Militar Nueva Granada.

Correspondencia: Francisco Javier Africano, javihalo_2@hotmail.com, u0401120@unimilitar.edu.co

Como citar: Africano FJ, Méndez IA, Holguin DF, Pachón DP, Rojas NA, Gonzalez IM. Comparison between Staphylococcus aureus, strains isolated from medical students in pre-clinical formation and clinical training. Cuarzo 2015; 21 (2): 55-60.

Recibido: 3 de marzo de 2015

Aceptado: 22 de mayo de 2015.

Publicado 15 de diciembre de 2015.

Licencia creative commons

\section{Abstract}

OBJECTIVE: To establish the differences between Staphylococcus aureus isolates from medical students in pre-clinical and clinical training and identify the level of susceptibility to methicillin, vancomycin and alternative antibiotics.

MATERIALS AND METHODS: A cross-sectional observational design with non-random sampling was used in medical students during pre-clinical and clinical training. Samples were taken from nasal swabs and cultured on blood agar. For beta-hemolytic gram-positive cocci, catalase and coagulase tests were performed and then cultured on mannitol salt agar. Susceptibility to cefoxitin, oxacillin, linezolid, clindamycin and trimethoprim sulfamethoxazole was assessed by using the Kirby-Bauer technique, and for vancomycin, an E-test was performed $\left(\right.$ Biomerieux $\left.^{\circledR}\right)$.

RESULTS: 51 strains of S. aureus from nasal swabs were isolated from 112 medical students. 68.6\% were identified as methicillinsensitive (MSSA) and 31.4\% as methicillin-resistant (MRSA). Four MRSA strains showed vancomycin intermediate (VISA 4-8 $\mu \mathrm{g} / \mathrm{mL}$ ) profile, $41 \%$ of MSSA isolates was resistant to clindamycin, $31 \%$ to linezolid and $23.5 \%$ to trimethoprim sulfamethoxazole.

DISCUSSION: MSSA, MRSA and VISA strains are present in nostrils of our medical students, with MRSA showing high resistance levels $(>50 \%)$ to clindamycin, TMP-SMX and linezolid, and MSSA levels up to $40 \%$. These findings reiterate the need to accomplish good nasal and hands hygiene in order to minimize the spread of $\mathrm{S}$. aureus in community and healthcare facilities.

KEYWORDS: Staphylococcus aureus, Antibiotic resistance. 


\section{Comparación entre cepas de Staphylococcus aureus aislados de estudiantes de medicina en entrenamiento pre-clínico y clínico}

OBJETIVO: establecer la prevalencia e identificar el perfil de resistencia a meticilina, vancomicina y antibióticos alternativos en aislamientos de Staphylococcus aureus provenientes de estudiantes de medicina en etapa de formación preclínica y en rotaciones hospitalarias.

MATERIALES Y MÉTODOS: estudio observacional transversal no aleatorizado en estudiantes de medicina durante entrenamiento clínico. Las muestras fueron tomadas de hisopados nasales y cultivadas en agar sangre. A los aislamientos identificados como cocos gram positivos se les realizó la prueba de catalasa, coagulasa y siembra en agar salado manitol. Para la evaluación de la prueba de susceptibilidad a cefoxitina, oxacilina, linezolida, clindamicina y trimetoprim sulfametoxazol se empleó la técnica de Kirby-Bauer y para la evaluación de la vancomicina el método de E-test (Biomerieux ${ }^{\circledR}$ ).

RESULTADOS: 51 cepas de S. aureus fueron aisladas de cavidad nasal de 112 estudiantes de medicina, 68,6 \% fueron identificadas como meticilino sensibles (SAMS) y 31,4\% como meticilino resistentes (SAMR). Cuatro cepas de SAMR mostraron ser vancomicina intermedio (SAVI 4-8 mg/mL), 41\% de los SAMS aislados fueron resistentes a la clindamicina, $31 \%$ al linezolid y $23,5 \%$ al trimetoprim sulfametoxazol.

DISCUSIÓN: En la cavidad nasal de estudiantes de medicina están presentes cepas de SAMS, SAMR y SAVI, los SAMR con alto nivel de resistencia (>50\%) para clindamicina, TMP-SMX y linezolid y hasta el 40\% para los SAMS. Estos resultados reiteran la necesidad de realizar una buena higiene nasal y de manos para reducir al mínimo la circulación de S. aureus en la comunidad y en los servicios de atención de la salud.

PALABRAS CLAVE: Staphylococcus aureus, resistencia antibiótica.

\section{Introduction}

Staphylococcus aureus has been recognized as one of the microorganisms with most impact even in patients with community acquired infections. S. aureus has a remarkable pathogenicity and the ability to adapt to different conditions and avoid the effect of antimicrobial treatment, thus generating huge costs and a high rate of mortality $(1,2)$.

S. aureus has been demonstrated in health care workers and in community; it causes about 30 deaths per day where a critical factor in morbidity and mortality is the use of inappropriate antibiotics. Methicillin-resistant (MRSA), vancomycin-intermediate (VISA) and a few vancomycinresistant (VRSA) strains of S. aureus have been isolated from people including patients (3-7). The intravenous vancomycin is the core treatment against MRSA (18), however many antibiotics such as clindamycin, trimethoprim sulfamethoxazole TMP-SMX, daptomycin and linezolid have been tested with similar therapeutic effect to vancomycin, minimal side effects and good recovery for patients (8-14).

Several studies in Colombia have found some strains of community acquired methicillin-resistant S. aureus (CA-MRSA); Sosa et al. and Villalobos et al. have showed the presence of CA-MRSA by using conventional and molecular typing in children and adults $(15,16)$. Similarly, S. aureus is an important nosocomial pathogen with resistance to oxacillin and other antibiotics (hospitalacquired-MRSA, HA-MRSA) (17).

Asymptomatic individuals will always be an important reservoir of S. aureus strains; they dwell on narines and skin and can be easily transmitted by fomites or direct contact with others (18).

Medical students are a particularly community, for that reason the objective of this research is to compare the prevalence between $\mathrm{S}$. aureus strains isolated from students during basic and clinical training and identify the level of susceptibility to several antibiotics. 


\section{Materials and methods}

A cross-sectional observational design with nonrandom sampling was used in 112 students (15 of pre-medical course, 15 in pre-clinical training and 82 with at least two-week clinical training) without antibiotic prescription or respiratory symptoms.

After signing the informed consent, samples were taken from nasal swabs (19-22) and they were processed by gram stain and cultured on blood agar (23). For beta hemolytic gram-positive cocci, catalase test was performed; if it was positive, then a coagulase test was performed and then it was cultured on mannitol salt agar (24).

Susceptibility of S. aureus to cefoxitin, oxacillin were performed to establish Methicilin resistant pattern, and linezolid, clindamycin, trimethoprim sulfamethoxazole (TMP-SMX) as therapeutic alternative antibiotics was assessed using the Kirby-Bauer technique (8, 9, 10, 25); vancomycin resistance was tested using E-test (Biomerieux $^{\circledR}$ ) (26). Results were reported according to the 2012 CLSI guidelines $(27,28)$. Incubation for all tests was performed at $35{ }^{\circ} \mathrm{C}$ under $5 \% \mathrm{CO}_{2}$ during 24 hours. In some cases for confirm the biotyping, we performed serotyping with commercial antiserum (Staphytect plusÒ oxoid) or Api 20 Staph (Biomerieux®).

\section{Results}

82 samples from nasal swabs were obtain from medical students in clinical training and 30 samples of students without clinical training, 41/82 and 10/30 samples of the respective groups mentioned above were typing with a $\mathrm{S}$. aureus isolate. In $61 \%(25 / 41)$ of students in clinical training group was identified a MSSA and in 39\% (16/41) were MRSA. Of the MRSA, $75 \%(12 / 16)$ were VSSA $(<$ $2 \mu \mathrm{g} / \mathrm{mL}$ ) and $25 \%$ (4 of 16 ) were VISA (4-8 ug/mL). In students without clinical training, a $100 \%$ of MSSA were isolated (Table 1).

For all MSSA isolates in the student in clinical training rotations, results from tests for alternative antimicrobials was $52 \%$ resistance to clindamycin, $24 \%$ to linezolid and $36 \%$ to trimethoprimsulfamethoxazole, in population without clinical training levels of resistance were of $30 \%$ to clindamycin, $40 \%$ to linezolid and $11,1 \%$ to trimethoprim-sulfamethoxazole (table 2).

\section{Discussion and conclusions}

Study was performed in a school of Medicine and in a fourth level hospital. Staphylococcus aureus strains were identified in nasal samples in 41 medical students in clinical training and 10 students in basic sciences. In a previous study conducted between 2009 - 2011, our group surveyed 155 students and scored a total of 455 gram-positive cocci (49,7\%), MRSA was more frequent with 22,7 $\%$ isolated from hands (29\%) and nose (23\%). Levels of $25 \%$ resistance to ampicillin/sulbactam and $37 \%$ to cephalexin, (29) were observed; Gandia et al found 30\% of MRSA in medical students in Sinú, Colombia (30). In both cases, the rate of MRSA isolates similar to the results obtained in the clinical population of students.

We observed an isolation of $50 \%$ of S. aureus of the samples collected from students during clinical training, of them 16 were MRSA (39\%). By contrast, seventy-two percent of healthcare workers at a university hospital in Bucaramanga Colombia were nasal carriers of S. aureus with 11,6\% of MRSA (15), those results are different from us, where we report less prevalence of S. aureus but more MRSA isolated.

A multicenter resistance study was performed between 2001 and 2009 in intensive care units; they report $11.2 \%$ of S. aureus and $45.6 \%$ of MRSA, compare to our medical students in clinical rotations the $\mathrm{S}$. aureus prevalence was lower (50\%) but MRSA was higher (39\%) (31). Regard to the isolates obtained in medical students without clinical training, none of them was a MRSA on the contrary sixteen MRSA were typing in students in clinical training. In a Cuba research study it highlight the fact that medical students are continuously exposed to environment highly loaded with microorganisms, including all types of S. aureus (23).

In the same way, Fosch et al in the town of Santa Fe, Argentina, found in 150 people from the community a $79,3 \%$ of samples positives to S. aureus of which just 3 were MRSA. In this population, $23,3 \%$ were resistant to clindamycin and 5,1\% to TMP- SXT (32).

In our study, MSSA isolates showed lower levels of resistance to TMP-SXT, but significant resistance to clindamycin (30\%-52\%) in both populations and for MRSA a high level of resistance to TMP-SXT (50\%) and a low resistance to clindamycin $(7,7 \%)$ is remarkable. 
TABLE 1. Distribution of $S$. aureus strains.

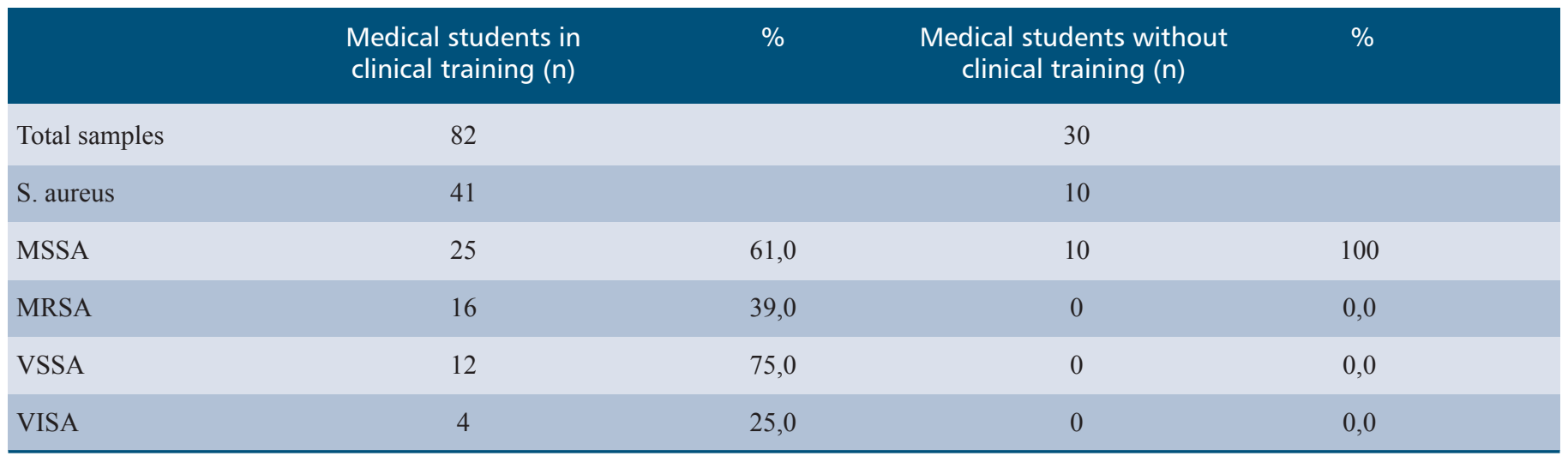

TABLE 2. Antimicrobial susceptibility profile of MSSA to antibiotics.

\begin{tabular}{|c|c|c|c|c|c|c|c|c|c|}
\hline & \multicolumn{3}{|c|}{ Clindamycin } & \multicolumn{3}{|c|}{ Linezolid } & \multicolumn{3}{|c|}{ TMP-SXT } \\
\hline $\begin{array}{l}\text { Medical students } \\
\text { without clinical training }\end{array}$ & 30 & 40 & 30 & 60 & 0 & 40 & 88,9 & 0 & 11,1 \\
\hline
\end{tabular}

Making a parallel between the two populations of our study, we see the remarkable difference in the isolation of profiles of S. aureus, since in population without hospital contact it was not found MRSA, also if we consider therapeutic alternative antibiotics is clear a high level of resistance to three antibiotics tested in both populations, as previously reported by Hernandez et al in Cuba (23).

Our results show that strains of MSSA, MRSA and VISA are present in a significant proportion in the nostrils of our medical students in clinical training compared to basic science students, but MRSA profile just were present during clinical training, probably as a consequence of contact with load atmosphere of microorganisms. In the same way, increased resistance to clindamycin, linezolid and TMP-SMX ranging from 30-52\% showed predominantly in clinical training students. Patients and health care workers are recognized as a source of pathogens, but medical students had not been recognized as interpreters in the transmission of MRSA. A good training in hands sanitation and emphasize in nasal hygiene to medical students especially in clinical rotations could be important to minimize this pervasive microorganism in community and health facilities. ACKNOWLEDGMENTS. We would like to thank the students of the School of Medicine, Universidad Militar, Bogotá, Colombia. We are grateful to the technicians Iveth Hernández for her helpful support in laboratory testing. FUNDS This work was supported by Grant MED 1360 from Researches Fund of Universidad Militar, Bogotá, Colombia. DISCLOSURE None of the researchers have conflict of interest.

\section{References}

1. Matlow A, Morris S. Control of antibiotic-resistant bacteria in the office and clinic. CMAJ 2009; 180(10):1021-1024.

2. Plata K, Rosato A, Wegrzyn G. Staphylococcus aureus as an infectious agent: overview of biochemistry and molecular genetics of its pathogenicity. Acta Biochem Polon 2009; 56(4):597-612. 
3. Paul M, Kariv G, Goldberg E, Raskin M, Shaked H, Hazzan R, et al. Importance of appropriate empirical antibiotic therapy for methicillin- resistant Staphylococcus aureus bacteremia. J Antimicrob Chemother 2010; 65: 2658-2665.

4. Rehm S, Tice A. Staphylococcus aureus: Methicillin- Susceptible S. aureus to Methicillin-Resistant S. aureus and Vancomycin-Resistant S. aureus. Clin Infect Dis 2010; 51(S2):176-182.

5. Cui L, Iwamoto A, Lian J, Neoh H, Maruyama T, Horikawa Y, et al. A Novel Mechanism of Antibiotic Resistance Originating in Vancomycin-Intermediate Staphylococcus aureus. Antimicrob Agents Chemother 2006; 50(2):428-238.

6. Liu C, Chambers H. Staphylococcus aureus with Heterogeneous Resistance to Vancomycin: Epidemiology, Clinical Significance, and Critical Assessment of Diagnostic Methods. Antimicrob Agents Chemother 2003; 47(10):3040- 3045.

7. Sieradzki K, Leski T, Dick J, Borio L, Tomasz A. Evolution of a Vancomycin-Intermediate Staphylococcus aureus Strain In Vivo: Multiple Changes in the Antibiotic Resistance Phenotypes of a Single Lineage of Methicillin- Resistant S. aureus under the Impact of Antibiotics Administered for Chemotherapy. J Clin Microbiol 2003; 41(4):1687-1693.

8. Frei C., Miller M., Lewis II J., Lawson K., Peddaiahgari R. Talbert R. Retrospective Cohort Study of Hospitalized Adults Treated With Vancomycin or Clindamycin for Methicillin- Resistant Staphylococcus aureus Skin Infections. Clin Ther. 2010; 32 (12):2024-2029.

9. Itani K, Dryden M, Bhattacharyya H, Kunkel M, Baruch A, Weigelt J. Efficacy and safety of linezolid versus vancomycin for the treatment of complicated skin and soft-tissue infections proven to be caused by methicillin- resistant Staphylococcus aureus. Am J Surg 2010; 199(6):804-816.

10. Balkhair A., Al Muharrmi b Z., Darwish L., Farhan H., Sallam M. Treatment of vancomycin-intermediate Staphylococcus aureus (VISA) endocarditis with linezolid. Int J Infect Dis 2010; 14:e227-e229.

11. Wang W, Lee S-Y, Chiueh T-S, Lu J-J. Molecular and Phenotypic Characteristics of Methicillin-Resistant and Vancomycin-Intermediate Staphylococcus aureus Isolates from Patients with Septic Arthritis. J Clin Microbiol 2009; 47(11):3617-3623.

12. Cui 1, Tominaga E, Neoh H, Hiramatsu K. Correlation between Reduced Daptomycin Susceptibility and Vancomycin Resistance in Vancomycin-Intermediate Staphylococcus aureus. Antimicrob Agents Chemother. 2006; 50(3):1079-1082.

13. Appleman M, Citron D. Efficacy of vancomycin and daptomycin against Staphylococcus aureus isolates collected over 29 years. Diagnostic Microbiol Infect Dis 2010; 66:441-444.

14. Hawser SP, Bouchillon SK, Hoban DJ, Dowzicky M, Babinchak T. Rising incidence of Staphylococcus aureus with reduced susceptibility to vancomycin and susceptibility to antibiotics: a global analysis 2004-2009. Intl J Antimicrob Agents 2011; 37:219224.

15. Sosa L, Machuca M, Sosa C, González C. Infecciones por Staphylococcus aureus meticilino resitente en niños en Bucaramanga Colombia. Salud UIS 2010; 42: 248-255.
16. Villalobos A, Díaz M, Barrero L, Rivera S, Henriquez D, Villegas M, Robledo C. Tendencias de los fenotipos de resistencia bacteriana en hospitales públicos y privados de alta complejidad de Colombia. Rev Panam Salud Publica.2011; 30(6):627-633.

17. Spirandelli K, Mamizuka E, Gontijo P. Methicillin/ Oxacillin-resistant Staphylococcus aureus as a hospital and public healt threat in Brazil. Brazilian J Infec Dis 2010; 14(1):71-76.

18. Morell E, Balkin D. Methicillin-resistant Staphylococcus aureus: A pervasive pathogen highlights the need for new antimicrobial development. Yale J Biol Med 2010; 83:223-233.

19. Cáceres M. Frecuencia de portadores nasales de Staphylococcus aureus resistente a meticilina en personal de salud de hospitales de Nicaragua. Rev Panam Salud Pública 2011; 30(6):610-614.

20. Seybold U, Schubert S, Bognera J, Hogardt M. Staphylococcus aureus infection following nasal colonization: an approach to rapid risk stratification in a university healthcare system. J Hosp Infect 2011; 79(1):297-301.

21. Rafee Y, Abdel-Haq N, Asmar B, Salimnia T, Vidaillac C, Rybak MJ, et al. Increased prevalence of methicillin-resistant Staphylococcus aureus nasal colonization in household contacts of children with community acquired disease. BMC Infect Dis 2012; 75(1):12-45

22. Creamer E, Dorrian S, Dolan A, Sherlock O, Fitzgerald- Hughes $\mathrm{D}$, Thomas $\mathrm{T}$, et al. When are the hands of healthcare workers positive for meticillin-resistant Staphylococcus aureus?. J Hosp Infect 2010; 75(1):107-111.

23. Hernández I, Toraño G, González M, González I. Staphylococcus aureus resistente a la meticilina: detección de portadores entre niños hospitalizados y niños sanos de la comunidad. Rev Cubana Med Trop 2003; 55(3):153-61.

24. Palavecino E. Métodos recomendados para el estudio de susceptibilidad en Staphylococcus aureus, Staphylococcus coagulasa negativa y Staphylococcus saprophyticus: Nuevos puntos de corte e interpretación de resultados. Rev Chil Infect 2002; 19(2):119124.

25. Mamani E, Luján D, Pajuelo G. Perfil de sensibilidad y resistencia de Staphylococcus aureus. Experiencia en el Hospital Nacional Hipólito Unanue. Annal Fac Med Lima 2006; 67(2):120-124.

26. Jaramillo S. Prueba Épsilon (Etest). Rev CES Med 1998; 12(1):34-41.

27. Clinical and Laboratory Standards Institute. Section 2C Performance standards for antimicrobial susceptibility testing; twentyfirst informational supplement. 2012; 32(3):70-89.

28. Malhotra-Kumar S, Haccuria K, Michiels M, Ieven M, Poyart C, Hryniewicz W, et al. MINIREVIEW. Current Trends in Rapid Diagnostics for Methicillin-Resistant Staphylococcus aureus and Glycopeptide-Resistant Enterococcus Species. J Clin Microbiol 2008; 46(5):1577-1587.

29. Méndez IA, Calixto OJ, Becerra WA, Vásquez JF, Bravo JS, Pachón DP. Microorganismos presentes en fonendoscopios, manos, cavidad oral y nasal de estudiantes de una facultad de Medicina. Rev MED. 2012. 20(1):90-100. 
30. Gandia JA, Benjumea Y, Mangones LM, Villacob KP, Sánchez L, Mosquera E. Prevalencia de Staphylococcus aureus meticilino resistente en estudiantes de medicina en la Universidad del Sinú. Report in Primer Encuentro nacional de semilleros de de investigación - facultades de Medicina, 2012 july 25-27, Bogotá, Colombia.
31. Espinosa C, Romero M, Rincón G, Bohórquez M, Arámbula A. Portadores nasales de Staphylococcus aureus en personal que labora en un hospital de Santander. Salud UIS 2011; 43(2):111-117.

32. Fosch S., Yones C., Trossero M., Grosso O., Nepote A. Portación nasal de Staphylococcus aureus en individuos de la comunidad: factores epidemiológicos. Acta Bioquím Clín Latinoam 2012; 46 (1): 59-67. 